Am J Transplant. 2013 March ; 13(Suppl 4): 138-146. doi:10.1111/ajt.12107.

\title{
Varicella Zoster Virus (VZV)
}

\author{
Steven A. Pergam ${ }^{1,2,3}$, Ajit P. Limaye ${ }^{1}$, and the AST Infectious Diseases Community of \\ Practice (COP) \\ ${ }^{1}$ Division of Allergy and Infectious Diseases, Department of Medicine, University of Washington, \\ Seattle, WA \\ 2 Vaccine and Infectious Disease Division, Fred Hutchinson Cancer Research Center, Seattle, \\ WA \\ ${ }^{3}$ Clinical Research Division, Fred Hutchinson Cancer Research Center, Seattle, WA
}

\section{Keywords}

Varicella; Herpes Zoster; Transplantation

\section{EPIDEMIOLOGY AND RISK FACTORS}

\section{Epidemiology}

Varicella zoster virus (VZV) is an exclusively human virus that exposure either through direct contact with a skin lesion or through airborne spread from respiratory droplets leads to acute varicella or "chickenpox." $(1,2)$ More than $90 \%$ of adults in the United States acquired the infection in childhood; in recent years most children and many young adults have been vaccinated with the live virus vaccine. $(1,3)$ The incubation time after primary exposure is approximately 10-21 days. Primary varicella typically presents with fever, constitutional symptoms and a vesicular, pruritic, widely disseminated rash that primarily involves the trunk and face (4); symptoms usually resolve within 7 to 10 days. Rates of hospitalization and mortality due to varicella have dropped with the institution of routine childhood varicella vaccination. $(5,6)$

After initial infection, VZV establishes lifelong latency in cranial nerve and dorsal root ganglia, and can reactivate years to decades later as herpes zoster (HZ) or "shingles".(7) Nearly all patients with HZ develop an exanthem of vesicular lesions in a dermatomal distribution. The annual incidence of $\mathrm{HZ}$ in the general population is 1.5 to 3.0 cases per 1,000 persons(1), and is estimated to occur in up to $20 \%$ of individuals during their lifetime. (8) Secondary complications such as bacterial superinfection and post-herpetic neuralgia (PHN) lead to increased morbidity.(9) 
All patients being considered for transplant should undergo serologic testing prior to transplantation to document prior exposure to VZV. Over $90 \%$ of adult solid organ transplant (SOT) recipients will be seropositive for VZV. Rates of seropositivity are lower in pediatric transplants $(10,11)$, but may improve with increased emphasis on varicella vaccination prior to transplantation.(3) Primary infection is rare in adult SOT recipients, but can be devastating, with visceral involvement, severe skin disease, and disseminated intravascular coagulation.(12-17) Herpes zoster is a frequent infectious complication in SOT recipients with an incidence of approximately $8-11 \%$ during the first four years posttransplant.(18-20) Dissemination similar to that seen in primary VZV infection is uncommon but has been reported in SOT and other immunocompromised populations; the level of immunosuppression may alter the risk of developing this complication.(15, 21, 22) Rates of PHN in SOT recipients may also be higher than in immunocompetent populations. (19)

\section{Risk Factors}

Primary Varicella-Susceptible seronegative patients are at risk for primary varicella. Studies have demonstrated that approximately 2-3\% of adult SOT recipients are seronegative for VZV.(11, 23) Donor transmitted VZV infection is rare but has been reported in a case where the donor had recently been treated for primary varicella.(24) Breakthrough varicella can occur in vaccinated patients but is usually a milder presentation when compared to wildtype primary infection. $(25,26)$ Data on risks of breakthrough varicella in immunocompromised patients who have previously been vaccinated for varicella are unknown.

Herpes Zoster-Patients with previous VZV infection or VZV vaccination are at risk for the development of HZ. Since there are no large prospective trials that have evaluated HZ in SOT, risk factors are not well defined. Similar to the general population, longitudinal studies have demonstrated that older transplant recipients are at greater risk for the development of HZ. $(18,20)$ Heart and lung transplant patients have increased rates of HZ compared to other transplant recipients, possibly related at least in part to more intensive immunosuppression. $(19,20,27,28)$ The use of mycophenolate mofetil (MMF) has also been suggested as a potential risk factor for the development of HZ. $(22,29,30)$ It is unknown whether the development of $\mathrm{HZ}$ prior to transplant lessens the risk for post-transplant recurrence. Similar to varicella, $\mathrm{HZ}$ can occur in patients who have previously received previously received varicella immunization, but the episodes are thought to milder than in patients who acquire natural infection with wild-type virus.(31)

\section{DIAGNOSIS}

In general, both primary varicella and HZ have typical clinical presentations that allow for a presumptive clinical diagnosis. Primary varicella presents as a disseminated pruritic rash that often starts on the face and spreads down the trunk, with relative sparing of the hands and soles of the feet; mucosal involvement can occur. One distinctive feature is that new lesions appear over several days so that most patients have papules, vesicles, and crusted lesions at the same time. $\mathrm{HZ}$ most often presents as a painful vesicular rash that involves $\_$adjacent 
unilateral dermatomes.(1) Presentations vary as patients may present with pain as a prodrome prior to the development of lesions, and pain may be less frequently seen in children and young adults. Herpes zoster ophthalmicus (trigeminal ganglion), Herpes zoster oticus (Ramsay-Hunt syndrome - geniculate ganglion), and other unique HZ presentations have been described elsewhere. $(32,33)$

Immunocompromised patients with $\mathrm{HZ}$ may develop disseminated skin lesions that can mimic primary varicella during periods of potent immunosuppression. $(34,35)$ SOT recipients are more likely to present atypically (34-36), may present with multi-organ involvement $(34,37)$ and can rarely develop invasive complications with delayed or absent rash. $(36,38)$ In SOT recipients, who may develop a multitude of other infectious and noninfectious rashes, laboratory testing is even more important than in the normal host, as a diagnosis may be more difficult to establish on clinical grounds alone.

Definitive laboratory testing can be used for atypical cases of VZV or $\mathrm{HZ}$ and should routinely be used for suspected disseminated, visceral disease or central nervous system disease. Rapid diagnostic methods, including polymerase chain reaction (PCR) and direct fluorescent assays (DFA), are the methods of choice.(39) PCR testing, the most sensitive test for VZV (40), can be used for detecting visceral involvement, and detects VZV in vesicle fluid, serum, spinal fluid, and other tissues. DFA is performed on scrapings taken from the base of a skin lesion, and is a rapid and reliable method for diagnosing VZV. Viral culture is specific and can help distinguish VZV from other viral pathogens such as Herpes simplex virus (HSV). Culture provides slower results and is less sensitive for VZV(41), but remains an important diagnostic entity, particularly since other viral infections (e.g. HSV) often do grow well in culture.

The majority of patients even without a history of clinical VZV infection will be seropositive $(42,43)$, regardless, all patients should undergo serologic testing to document prior exposure to VZV during their pre-transplant evaluation process. Serology results can be used to determine post-transplant risk as patients who are seronegative prior to transplant are at risk for the development of primary VZV, and seropositive patients are at risk for developing post-transplant HZ. It is important to note that in acute infections serologic testing should be interpreted with caution. False-negative serologic results are more common in immunocompromised patients and may be seen during primary infection, and false-positive results can also occur following transfusions; serology should not be used for diagnosing acute infections in this population.(39)

\section{TREATMENT (see Table 1)}

Treatment recommendations are listed in Table 1. It is important to note that doses given in the table are given for patients with preserved renal function. In patients with renal dysfunction dosing should be reviewed prior to administration, since most agents will require appropriate dose modification. 


\section{Varicella}

Post-transplant patients who develop primary varicella are at risk for developing severe infection and should be treated with intravenous acyclovir (Table 1).(44-46) (II-1) Therapy initiated early in the course of the illness, especially within 24-hours of rash onset, maximizes efficacy.(39) Reduction in immunosuppressive therapy should be considered (III) (16), but to facilitate an appropriate stress response, steroid dosing should be maintained or may need to be temporarily boosted based on clinical findings. Non-specific intravenous immunoglobulin (IVIG) or VZV immunoglobulin are unlikely to provide additional benefits to those with established infection and are therefore not recommended.(39) However, IVIG and Varicella zoster immune globulin (VZIG) have been used anecdotally in those with severe infection (III).(15, 47-50)

\section{Herpes Zoster}

Patients with disseminated or organ invasive disease should be treated with IV acyclovir (II-2). $(44,46)$ Localized non-severe dermatomal $\mathrm{HZ}$ can be treated with oral valacyclovir or famciclovir as an outpatient in most adults with close follow-up (II-1).(51, 52) Two notable exceptions for those with localized infection are those within the trigeminal ganglion (herpes zoster ophthalmicus) which may be sight-threatening, and involvement of the geniculate ganglion (herpes zoster oticus / Ramsay-Hunt syndrome) which can lead to facial palsy.(53) These patients should preferably receive IV acyclovir therapy, and in cases of trigeminal involvement, prompt ophthalmologic consultation to avoid major ocular complications (III). There are no data that support adding glucocorticoids to patients on steroid-sparring regimens to prevent late PHN complications so this is not recommended (III).

\section{PREVENTION/PROPHYLAXIS (see Table 2)}

Suggestions for prevention and prophylaxis are listed in Table 2. Doses given in the table are given for patients with preserved renal function, so patients with renal dysfunction dosing may need appropriate dose modification.

\section{VZV Prevention}

Antiviral therapy-Oral acyclovir and its pro-drugs have been shown to prevent VZV reactivation in other immunosuppressed populations, but they have not been systematically studied in SOT recipients (Table 2).(54) During the early post-transplant period, many current regimens used for cytomegalovirus (CMV) prevention will likely prevent VZV reactivation, and therefore additional antiviral prophylaxis for VZV is not needed during periods of CMV prophylaxis [valganciclovir, ganciclovir, or high dose acyclovir].(55-57) In patients who do not receive CMV prophylaxis, short term antivirals [acyclovir, valganciclovir] given for herpes simplex (HSV) prophylaxis may also be effective against VZV during the period immediately post-transplant (III). Prophylactic antiviral agents for patients who are both CMV/HSV seronegative but VZV seropositive have not been studied, but it seems prudent to consider similar strategies to patients receiving HSV prophylaxis to provide at least minimal protection during the high-risk post-transplant period (III). Since the length of immunosuppression is life-long in most SOT recipients, an increased risk for $\mathrm{HZ}$ is continuous after transplantation.(18-20) While effective for short-term use (58), 
insufficient data exist to recommend routine use of long-term VZV prophylaxis in SOT recipients (III).

Pre-Transplant Vaccination-Potential transplant patients who are susceptible to VZV, should be given varicella vaccination with the live attenuated Oka vaccine (Varivax®, Merck \& Co, Inc., USA) provided no contraindications are present (II-1). Multiple non-randomized studies in subjects with end-stage renal disease have demonstrated that the Oka vaccine is safe and effective prior to transplant.(23, 59-61) While fewer data are available in subjects with end-stage liver disease, the Oka vaccine also appears to be safe if given pre-transplant to these patients (II-2).(62-64) Little data exist for other pre-transplant patients but the vaccine is likely safe in these populations (III).(65) Patients with end-stage organ disease have reduced seroconversion rates to varicella vaccination $[\sim 60 \%](59-61,64)$, so two doses should be given prior to transplantation if practical with a minimal interval of 4 to 6 weeks. $(57,66,67)$ Patients should be vaccinated at least 2 to 4 weeks prior to transplant $(67)$, but if the vaccine is given in conjunction with measles, mumps, rubella vaccine (MMR and Varicella combined vaccine [ProQuad®, Merck \& Co., Inc, USA]) it should be administered at least 4 weeks prior to transplant.

The current HZ vaccine (Zostavax ${ }^{\circledR}$, Merck \& Co., Inc., USA) contains approximately ten times more plaque forming units of live-virus then current Oka varicella vaccines. This vaccine has not been studied in patients with end-organ disease awaiting transplant, but could be considered on a case by case basis for those who meet current criteria for $\mathrm{HZ}$ vaccination (III).

Post-Transplant Vaccination-The Oka varicella vaccines have been shown to be safe in select children undergoing chemotherapy and small studies have demonstrated that they can be given safely to post-transplant recipients receiving immunosuppression.(68-71) While varicella vaccination has been given safely to small numbers of susceptible SOT recipients $(70,71)$, caution should be used with the use of this live-virus vaccine as it is currently not approved for immunocompromised patients (III). In addition, rates of seroconversion in immunocompromised patients may not be as robust as in those with intact immune systems. The $\mathrm{HZ}$ vaccine poses a risk of disseminated infection in immunosuppressed patients and therefore is contraindicated for post-transplant recipients (III).

\section{Post-Exposure Prophylaxis}

Seronegative transplant recipients are at risk for developing severe primary infection after exposure and should, after a significant exposure, receive post-exposure prophylaxis (II-1). In the outpatient environment significant exposure to VZV has been defined as exposure to a household contact or non-transient face-to-face contact indoors with a playmate or other contact. In the hospital significant exposure to VZV is defined as exposure in the same 2 to 4-bed room, face-to-face contact with an infectious staff member or patient, or a visit by a person deemed contagious.(39) VZV can be spread through direct contact and airborne contacts from a person with active varicella. Patients with HZ may transmit VZV to a person 
who has never had varicella through direct contact with the rash. There is emerging evidence that VZV may be spread through an airborne route even from localized HZ.(2, 72-74)

Options for post-exposure prophylaxis include passive immunoprophylaxis and/or antiviral therapy. VZIG is no longer available in most centers, and a non-FDA-licensed VZV immune globulin VariZIG ${ }^{\mathrm{TM}}$ (Cangene Corporation, Winnipeg, Canada) may be the only VZV specific immunoprophylaxis available.(3) In the United States it is available only through an investigational new drug application, lack of rapid access may further limit the use of VariZIG at many centers.(75) If available, VZIG or VariZIG is recommended in susceptible patients exposed to VZV and should be given as soon as possible but within at least 10 days of exposure (II-1).(39, 76) Immunoprophylaxis alone does not prevent all immunosuppressed patients from developing clinical varicella but lessens the severity of infection.(77-79) Although not studied in clinical trials, non-specific IVIG has been suggested as an alternate post-exposure prophylaxis when VariZIG is not available (39); combination use of IVIG with antiviral therapy in immunocompromised patients can also be considered (III).

The use of antiviral agents as post-exposure prophylaxis has not been evaluated in randomized clinical trials in immunocompromised patients, but should be considered as adjunctive therapy in patients receiving immunoprophylaxis or in patients who were unable to receive immunoprophylaxis prior to 10 days after their exposure (III).(76) The value of acyclovir as post-exposure prophylaxis has been demonstrated in a study of immunocomponent children (80) and has been suggested to be effective (in addition to VZIG) in a small study of high-risk children which included 5 kidney transplant recipients. (81) Due to the unpredictable absorption and low bioavailability of oral acyclovir $(82,83)$, valacyclovir, which has improved bioavailability (84), may be preferred for prophylaxis (III). Current recommendations are for patients to receive acyclovir or valacyclovir for a 7 day course of therapy beginning 7 to 10 days after varicella exposure (III).(39) Alternatively, some experts believe those who are highly immunosuppressed should receive longer antiviral prophylaxis from days 3 to 22 after known exposure and from days 3 to 28 if given immunoprophylaxis (III). $(85,86)$

\section{INFECTION CONTROL ISSUES}

All immunosuppressed patients admitted to the hospital with varicella or $\mathrm{HZ}$ should be placed on airborne and contact isolation, and close contacts who are susceptible to VZV should be immunized as soon as possible (preferably within 3 days of exposure with possible efficacy as late as 5 days post-exposure) or given appropriate VZV prophylaxis (IIB).(39) Patients should be isolated until at least all lesions are crusted, which can be delayed in immuncompromised patients.(39) In addition to post-exposure prophylaxis, exposed susceptible patients should remain in airborne and contact precautions from day 10 to 21 while in the hospital after exposure to the index patient, and those who receive VariZIG or IVIG should remain in precautions until day 28.(39) Patients with localized zoster lesions should also have them covered as this can potentially decrease transmission risk.(74) 
Since secondary cases of VZV in a household setting can be more severe due to exposure to a higher titer of virus (87), vaccination of close household members is an important part of prevention. Vaccinated individuals are at least $50 \%$ less contagious when they develop varicella and secondary attack rates are much lower.(88) Close contacts and family members 12 months or older should be vaccinated for VZV if they have never received the vaccination, have no history of varicella or $\mathrm{HZ}$, and have no contraindications to vaccination (I). Transplant recipients should be isolated from vaccinated contacts who develop a varicella-like rash, particularly those with $>50$ lesions, as vaccine associated rashes can result in transmission.(88)

\section{FUTURE RESEARCH ISSUES}

Studies are currently underway to evaluate the safety and efficacy of pre-transplant vaccination for $\mathrm{HZ}$ in seropositive recipients. $(89,90)$ Large randomized trials evaluating safety and efficacy of both varicella and $\mathrm{HZ}$ vaccines in post-transplant patients are also needed. Inactivated VZV vaccines, which are in development, may eventually provide another option for this high-risk population.(91) Additional studies to assess the use of lowdose antiviral therapy as long term post-exposure prophylaxis are also needed. Finally, as new immunosuppressive agents are developed, they will need to be evaluated both in terms of altering risk for $\mathrm{HZ}$ post-transplant as well as their effect on vaccine efficacy.

\section{Acknowledgments}

Financial Support: S.A.P. is supported by NIH grant K23HL096831 and an ASBMT/Viropharma New Investigator Award. APL is supported in part by NIH grant 5UO1 HL10254703.

\section{KEY REFERENCES}

1. Gnann JW Jr. Whitley RJ. Clinical practice. Herpes zoster. N Engl J Med. 2002; 347:340-346. [PubMed: 12151472]

2. Sawyer MH, Chamberlin CJ, Wu YN, Aintablian N, Wallace MR. Detection of varicella-zoster virus DNA in air samples from hospital rooms. J Infect Dis. 1994; 169:91-94. [PubMed: 8277202]

3. Marin M, Guris D, Chaves SS, Schmid S, Seward JF. Prevention of varicella: recommendations of the Advisory Committee on Immunization Practices (ACIP). MMWR Recomm Rep. 2007; 56:1-40.

4. Heininger U, Seward JF. Varicella. Lancet. 2006; 368:1365-1376. [PubMed: 17046469]

5. Nguyen HQ, Jumaan AO, Seward JF. Decline in mortality due to varicella after implementation of varicella vaccination in the United States. N Engl J Med. 2005; 352:450-458. [PubMed: 15689583]

6. Davis MM, Patel MS, Gebremariam A. Decline in varicella-related hospitalizations and expenditures for children and adults after introduction of varicella vaccine in the United States. Pediatrics. 2004; 114:786-792. [PubMed: 15342855]

7. Gilden DH, Kleinschmidt-DeMasters BK, LaGuardia JJ, Mahalingam R, Cohrs RJ. Neurologic complications of the reactivation of varicella-zoster virus. N Engl J Med. 2000; 342:635-645. [PubMed: 10699164]

8. Straus SE, Ostrove JM, Inchauspe G, Felser JM, Freifeld A, Croen KD, Sawyer MH. NIH conference. Varicella-zoster virus infections. Biology, natural history, treatment, and prevention. Ann Intern Med. 1988; 108:221-237. [PubMed: 2829675]

9. Johnson RW. The future of predictors, prevention, and therapy in postherpetic neuralgia. Neurology. 1995; 45:S70-72. [PubMed: 8545029] 
10. Crespo JF, Gorriz JL, Avila A, Sancho A, Gavela E, Cano A, Zanon V, et al. Prevalence of past varicella zoster virus infection in candidates for kidney transplantation: vaccination in seronegative patients. Transplant Proc. 2002; 34:77. [PubMed: 11959193]

11. Geel AL, Landman TS, Kal JA, van Doomum GJ, Weimar W. Varicella zoster virus serostatus before and after kidney transplantation, and vaccination of adult kidney transplant candidates. Transplant Proc. 2006; 38:3418-3419. [PubMed: 17175291]

12. Pandya A, Wasfy S, Hebert D, Allen UD. Varicella-zoster infection in pediatric solid-organ transplant recipients: a hospital-based study in the prevaricella vaccine era. Pediatr Transplant. 2001; 5:153-159. [PubMed: 11422816]

13. Furth SL, Sullivan EK, Neu AM, Tejani A, Fivush BA. Varicella in the first year after renal transplantation: a report of the North American Pediatric Renal Transplant Cooperative Study (NAPRTCS). Pediatr Transplant. 1997; 1:37-42. [PubMed: 10084785]

14. Rodriguez-Moreno A, Sanchez-Fructuoso AI, Calvo N, Ridao N, Conesa J, Marques M, Prats D, et al. Varicella infection in adult renal allograft recipients: experience at one center. Transplant Proc. 2006; 38:2416-2418. [PubMed: 17097954]

15. Fehr T, Bossart W, Wahl C, Binswanger U. Disseminated varicella infection in adult renal allograft recipients: four cases and a review of the literature. Transplantation. 2002; 73:608-611. [PubMed: 11889440]

16. Feldhoff CM, Balfour HH Jr. Simmons RL, Najarian JS, Mauer SM. Varicella in children with renal transplants. J Pediatr. 1981; 98:25-31. [PubMed: 7005416]

17. McGregor RS, Zitelli BJ, Urbach AH, Malatack JJ, Gartner JC Jr. Varicella in pediatric orthotopic liver transplant recipients. Pediatrics. 1989; 83:256-261. [PubMed: 2536479]

18. Arness T, Pedersen R, Dierkhising R, Kremers W, Patel R. Varicella zoster virus-associated disease in adult kidney transplant recipients: incidence and risk-factor analysis. Transpl Infect Dis. 2008; 10:260-268. [PubMed: 18086277]

19. Gourishankar S, McDermid JC, Jhangri GS, Preiksaitis JK. Herpes zoster infection following solid organ transplantation: incidence, risk factors and outcomes in the current immunosuppressive era. Am J Transplant. 2004; 4:108-115. [PubMed: 14678041]

20. Pergam SA, Forsberg CW, Boeckh MJ, Maynard C, Limaye AP, Wald A, Smith NL, et al. Herpes zoster incidence in a multicenter cohort of solid organ transplant recipients. Transpl Infect Dis. 2011; 13:15-23. [PubMed: 20636480]

21. Koc Y, Miller KB, Schenkein DP, Griffith J, Akhtar M, DesJardin J, Snydman DR. Varicella zoster virus infections following allogeneic bone marrow transplantation: frequency, risk factors, and clinical outcome. Biol Blood Marrow Transplant. 2000; 6:44-49. [PubMed: 10707998]

22. Lauzurica R, Bayes B, Frias C, Fontsere N, Hernandez A, Matas L, Jimenez A, et al. Disseminated varicella infection in adult renal allograft recipients: role of mycophenolate mofetil. Transplant Proc. 2003; 35:1758-1759. [PubMed: 12962784]

23. Geel A, Zuidema W, van Gelder T, van Doornum G, Weimar W. Successful vaccination against varicella zoster virus prior to kidney transplantation. Transplant Proc. 2005; 37:952-953.

[PubMed: 15848586]

24. Fall AJ, Aitchison JD, Krause A, Hasan A, Hamilton JR, Gould FK. Donor organ transmission of varicella zoster due to cardiac transplantation. Transplantation. 2000; 70:211-213. [PubMed: 10919605]

25. Watson BM, Piercy SA, Plotkin SA, Starr SE. Modified chickenpox in children immunized with the Oka/Merck varicella vaccine. Pediatrics. 1993; 91:17-22. [PubMed: 8416499]

26. Chaves SS, Zhang J, Civen R, Watson BM, Carbajal T, Perella D, Seward JF. Varicella disease among vaccinated persons: clinical and epidemiological characteristics, 1997-2005. J Infect Dis. 2008; 197(Suppl 2):S127-131. [PubMed: 18419385]

27. Fuks L, Shitrit D, Fox BD, Amital A, Raviv Y, Bakal I, Kramer MR. Herpes zoster after lung transplantation: incidence, timing, and outcome. Ann Thorac Surg. 2009; 87:423-426. [PubMed: 19161751]

28. Manuel O, Kumar D, Singer LG, Cobos I, Humar A. Incidence and clinical characteristics of herpes zoster after lung transplantation. J Heart Lung Transplant. 2008; 27:11-16. [PubMed: $18187081]$ 
29. Satoh S, Tada H, Murakami M, Tsuchiya N, Inoue T, Togashi H, Matsuura S, et al. The influence of mycophenolate mofetil versus azathioprine and mycophenolic acid pharmacokinetics on the incidence of acute rejection and infectious complications after renal transplantation. Transplant Proc. 2005; 37:1751-1753. [PubMed: 15919454]

30. Triemer HL, Pearson TC, Odom KL, Larsen CP. Analysis of a single-center experience with mycophenolate mofetil based immunosuppression in renal transplantation. Clin Transplant. 2000; 14:413-420. [PubMed: 10946781]

31. Civen R, Chaves SS, Jumaan A, Wu H, Mascola L, Gargiullo P, Seward JF. The incidence and clinical characteristics of herpes zoster among children and adolescents after implementation of varicella vaccination. Pediatr Infect Dis J. 2009; 28:954-959. [PubMed: 19536039]

32. Volpi A. Severe complications of herpes zoster. Herpes. 2007; 14(Suppl 2):35-39. [PubMed: 17939894]

33. Gnann JW Jr. Varicella-zoster virus: atypical presentations and unusual complications. J Infect Dis. 2002; 186(Suppl 1):S91-98. [PubMed: 12353193]

34. Alvite-Canosa M, Paniagua-Martin MJ, Quintela-Fandino J, Otero A, Crespo-Leiro MG. Fulminant hepatic failure due to varicella zoster in a heart transplant patient: successful liver transplant. J Heart Lung Transplant. 2009; 28:1215-1216. [PubMed: 19782606]

35. Oh KH, Ahn C, Kim YS, Han JS, Kim S, Lee JS, Kim EC, et al. Atypical generalized zoster with suspicious esophageal involvement and early relapse in an adult renal transplant recepient. Transplant Proc. 2002; 34:1174-1177. [PubMed: 12072307]

36. Hovens MM, Vaessen N, Sijpkens YW, de Fijter JW. Unusual presentation of central nervous system manifestations of Varicella zoster virus vasculopathy in renal transplant recipients. Transpl Infect Dis. 2007; 9:237-240. [PubMed: 17692072]

37. Verleden GM, Vos R, Van Raemdonck DE, Laleman W, Vanaudenaerde BM. Acute liver failure due to varicella zoster virus infection after lung transplantation: a case report. Transplant Proc. 2012; 44:1457-1459. [PubMed: 22664036]

38. Assi M, Abou Antoun S. Unusual neurologic manifestations of varicella zoster virus infection with the absence of rash in a kidney transplant recipient. Transpl Infect Dis. 2011; 13:545-547. [PubMed: 21338462]

39. American Academy of Pediatrics. Varicella-Zoster Infections.. In: Pickering, LK.Baker, CJ.Kimberlin, DW., Long, SS., editors. Red Book 2012: Report of the Committee on Infectious Diseases. 29th ed.. American Academy of Pediatrics; Elk Grove Village, IL: 2012. p. 774-789.p. 841-847.

40. Taha YA, Quinlivan M, Scott FT, Leedham-Green M, Hawrami K, Thomas JM, Breuer J. Are false negative direct immnufluorescence assays caused by varicella zoster virus gE mutant strains? J Med Virol. 2004; 73:631-635. [PubMed: 15221911]

41. Coffin SE, Hodinka RL. Utility of direct immunofluorescence and virus culture for detection of varicella-zoster virus in skin lesions. J Clin Microbiol. 1995; 33:2792-2795. [PubMed: 8567930]

42. Breuer J, Schmid DS, Gershon AA. Use and limitations of varicella-zoster virus-specific serological testing to evaluate breakthrough disease in vaccinees and to screen for susceptibility to varicella. J Infect Dis. 2008; 197(Suppl 2):S147-151. [PubMed: 18419389]

43. Brunell PA, Wood D. Varicella serological status of healthcare workers as a guide to whom to test or immunize. Infect Control Hosp Epidemiol. 1999; 20:355-357. [PubMed: 10349958]

44. Balfour HH Jr. McMonigal KA, Bean B. Acyclovir therapy of varicella-zoster virus infections in immunocompromised patients. J Antimicrob Chemother. 1983; 12(Suppl B):169-179.

45. Carcao MD, Lau RC, Gupta A, Huerter H, Koren G, King SM. Sequential use of intravenous and oral acyclovir in the therapy of varicella in immunocompromised children. Pediatr Infect Dis J. 1998; 17:626-631. [PubMed: 9686730]

46. Shepp DH, Dandliker PS, Meyers JD. Treatment of varicella-zoster virus infection in severely immunocompromised patients. A randomized comparison of acyclovir and vidarabine. N Engl J Med. 1986; 314:208-212. [PubMed: 3001523]

47. Sulliger JM, Imbach P, Barandun S, Gugler E, Hirt A, Luthy A, Rossi E, et al. Varicella and herpes zoster in immunosuppressed children: preliminary results of treatment with intravenous immunoglobulin. Helv Paediatr Acta. 1984; 39:63-70. [PubMed: 6609911] 
48. Vales-Albertos LJ, Andrade-Sierra J, Gomez-Navarro B, Monteon-Ramos F, Rodriguez-Perez M, Torres-Lozano C, Cueto-Manzano AM. Nonspecific immunoglobulin and granulocyte-macrophage colony-stimulating factor use in complicated varicella zoster: the first case report in a renal transplant recipient. Transplantation. 2006; 81:809-810. [PubMed: 16534489]

49. Kashtan CE, Cook M, Chavers BM, Mauer SM, Nevins TE. Outcome of chickenpox in 66 pediatric renal transplant recipients. J Pediatr. 1997; 131:874-877. [PubMed: 9427893]

50. Prelog M, Schonlaub J, Zimmerhackl LB. Aciclovir and varicella-zosterimmunoglobulin in solidorgan transplant recipients. Pediatr Nephrol. 2011; 26:663-673. [PubMed: 21076967]

51. Tyring S, Belanger R, Bezwoda W, Ljungman P, Boon R, Saltzman RL. A randomized, doubleblind trial of famciclovir versus acyclovir for the treatment of localized dermatomal herpes zoster in immunocompromised patients. Cancer Invest. 2001; 19:13-22. [PubMed: 11291551]

52. Arora A, Mendoza N, Brantley J, Yates B, Dix L, Tyring S. Double-blind study comparing 2 dosages of valacyclovir hydrochloride for the treatment of uncomplicated herpes zoster in immunocompromised patients 18 years of age and older. J Infect Dis. 2008; 197:1289-1295. [PubMed: 18422441]

53. Otsuki K, Kenmochi T, Maruyama M, Akutsu N, Iwashita C, Ito T, Matsumoto I, et al. A case of Ramsay Hunt syndrome in living-kidney transplant recipient. Transplant Proc. 2012; 44:307-308. [PubMed: 22310640]

54. Erard V, Guthrie KA, Varley C, Heugel J, Wald A, Flowers ME, Corey L, et al. One-year acyclovir prophylaxis for preventing varicella-zoster virus disease after hematopoietic cell transplantation: no evidence of rebound varicella-zoster virus disease after drug discontinuation. Blood. 2007; 110:3071-3077. [PubMed: 17515400]

55. Lowance D, Neumayer HH, Legendre CM, Squifflet JP, Kovarik J, Brennan PJ, Norman D, et al. Valacyclovir for the prevention of cytomegalovirus disease after renal transplantation. International Valacyclovir Cytomegalovirus Prophylaxis Transplantation Study Group. N Engl J Med. 1999; 340:1462-1470. [PubMed: 10320384]

56. Gane E, Saliba F, Valdecasas GJ, O'Grady J, Pescovitz MD, Lyman S, Robinson CA. Randomised trial of efficacy and safety of oral ganciclovir in the prevention of cytomegalovirus disease in livertransplant recipients. The Oral Ganciclovir International Transplantation Study Group [corrected]. Lancet. 1997; 350:1729-1733. [PubMed: 9413463]

57. Humar A. Reactivation of viruses in solid organ transplant patients receiving cytomegalovirus prophylaxis. Transplantation. 2006; 82:S9-S14.

58. Fiddian P, Sabin CA, Griffiths PD. Valacyclovir provides optimum acyclovir exposure for prevention of cytomegalovirus and related outcomes after organ transplantation. J Infect Dis. 2002; 186(Suppl 1):S110-115. [PubMed: 12353195]

59. Furth SL, Hogg RJ, Tarver J, Moulton LH, Chan C, Fivush BA. Varicella vaccination in children with chronic renal failure. A report of the Southwest Pediatric Nephrology Study Group. Pediatr Nephrol. 2003; 18:33-38. [PubMed: 12488988]

60. Webb NJ, Fitzpatrick MM, Hughes DA, Brocklebank TJ, Judd BA, Lewis MA, Postlethwaite RJ, et al. Immunisation against varicella in end stage and pre-end stage renal failure. Trans-Pennine Paediatric Nephrology Study Group. Arch Dis Child. 2000; 82:141-143. [PubMed: 10648369]

61. Broyer M, Tete MJ, Guest G, Gagnadoux MF, Rouzioux C. Varicella and zoster in children after kidney transplantation: long-term results of vaccination. Pediatrics. 1997; 99:35-39. [PubMed: 8989334]

62. Kano H, Mizuta K, Sakakihara Y, Kato H, Miki Y, Shibuya N, Saito M, et al. Efficacy and safety of immunization for pre- and post- liver transplant children. Transplantation. 2002; 74:543-550. [PubMed: 12352917]

63. Nithichaiyo C, Chongsrisawat V, Hutagalung Y, Bock HL, Poovorawa Y. Immunogenicity and adverse effects of live attenuated varicella vaccine (Oka-strain) in children with chronic liver disease. Asian Pac J Allergy Immunol. 2001; 19:101-105. [PubMed: 11699716]

64. Barton M, Wasfy S, Melbourne T, Hebert D, Moore D, Robinson J, Marchese RD, et al. Sustainability of humoral responses to varicella vaccine in pediatric transplant recipients following a pretransplantation immunization strategy. Pediatr Transplant. 2009; 13:1007-1013. [PubMed: 19207222] 
65. Benden C, Danziger-Isakov LA, Astor T, Aurora P, Bluemchen K, Boyer D, Conrad C, et al. Variability in immunization guidelines in children before and after lung transplantation. Pediatr Transplant. 2007; 11:882-887. [PubMed: 17976123]

66. Levin MJ. Varicella vaccination of immunocompromised children. J Infect Dis. 2008; 197(Suppl 2):S200-206. [PubMed: 18419398]

67. Burroughs M, Moscona A. Immunization of pediatric solid organ transplant candidates and recipients. Clin Infect Dis. 2000; 30:857-869. [PubMed: 10852737]

68. Khan S, Erlichman J, Rand EB. Live virus immunization after orthotopic liver transplantation. Pediatr Transplant. 2006; 10:78-82. [PubMed: 16499592]

69. Weinberg A, Horslen SP, Kaufman SS, Jesser R, Devoll-Zabrocki A, Fleckten BL, Kochanowicz S, et al. Safety and immunogenicity of varicella-zoster virus vaccine in pediatric liver and intestine transplant recipients. Am J Transplant. 2006; 6:565-568. [PubMed: 16468967]

70. Zamora I, Simon JM, Da Silva ME, Piqueras AI. Attenuated varicella virus vaccine in children with renal transplants. Pediatr Nephrol. 1994; 8:190-192. [PubMed: 8018498]

71. Chaves Tdo S, Lopes MH, de Souza VA, Dos Santos Sde S, Pereira LM, Reis AD, David-Neto E. Seroprevalence of antibodies against varicella-zoster virus and response to the varicella vaccine in pediatric renal transplant patients. Pediatr Transplant. 2005; 9:192-196. [PubMed: 15787792]

72. Josephson A, Gombert ME. Airborne transmission of nosocomial varicella from localized zoster. J Infect Dis. 1988; 158:238-241. [PubMed: 3392417]

73. Lopez AS, Burnett-Hartman A, Nambiar R, Ritz L, Owens P, Loparev VN, Guris D, et al. Transmission of a newly characterized strain of varicella-zoster virus from a patient with herpes zoster in a long-term-care facility, West Virginia, 2004. J Infect Dis. 2008; 197:646-653. [PubMed: 18260757]

74. Harpaz R, Ortega-Sanchez IR, Seward JF. Prevention of herpes zoster: recommendations of the Advisory Committee on Immunization Practices (ACIP). MMWR Recomm Rep. 2008; 57:1-30.

75. A new product (VariZIG) for postexposure prophylaxis of varicella available under an investigational new drug application expanded access protocol. MMWR Morb Mortal Wkly Rep. 2006; 55:209-210. [PubMed: 16511443]

76. FDA approval of an extended period for administering VariZIG for postexposure prophylaxis of varicella. MMWR Morb Mortal Wkly Rep. 2012; 61:212. [PubMed: 22456121]

77. Zaia JA, Levin MJ, Preblud SR, Leszczynski J, Wright GG, Ellis RJ, Curtis AC, et al. Evaluation of varicella-zoster immune globulin: protection of immunosuppressed children after household exposure to varicella. J Infect Dis. 1983; 147:737-743. [PubMed: 6341478]

78. Orenstein WA, Heymann DL, Ellis RJ, Rosenberg RL, Nakano J, Halsey NA, Overturf GD, et al. Prophylaxis of varicella in high-risk children: dose-response effect of zoster immune globulin. $\mathrm{J}$ Pediatr. 1981; 98:368-373. [PubMed: 7205447]

79. Hanngren K, Falksveden L, Grandien M, Lidin-Janson G. Zoster immunoglobulin in varicella prophylaxis. A study among high-risk patients. Scand J Infect Dis. 1983; 15:327-334. [PubMed: 6318302]

80. Suga S, Yoshikawa T, Ozaki T, Asano Y. Effect of oral acyclovir against primary and secondary viraemia in incubation period of varicella. Arch Dis Child. 1993; 69:639-642. discussion 642-633. [PubMed: 8285774]

81. Goldstein SL, Somers MJ, Lande MB, Brewer ED, Jabs KL. Acyclovir prophylaxis of varicella in children with renal disease receiving steroids. Pediatr Nephrol. 2000; 14:305-308. [PubMed: 10775074]

82. Amini H, Javan M, Gazerani P, Ghaffari A, Ahmadiani A. Lack of bioequivalence between two aciclovir tablets in healthy subjects. Clin Drug Investig. 2008; 28:47-53.

83. de Miranda P, Blum MR. Pharmacokinetics of acyclovir after intravenous and oral administration. $\mathrm{J}$ Antimicrob Chemother. 1983; 12(Suppl B):29-37.

84. Hoglund M, Ljungman P, Weller S. Comparable aciclovir exposures produced by oral valaciclovir and intravenous aciclovir in immunocompromised cancer patients. J Antimicrob Chemother. 2001; 47:855-861. [PubMed: 11389118]

85. Boeckh M. Prevention of VZV infection in immunosuppressed patients using antiviral agents. Herpes. 2006; 13:60-65. [PubMed: 17147908] 
86. Weinstock DM, Boeckh M, Boulad F, Eagan JA, Fraser VJ, Henderson DK, Perl TM, et al. Postexposure prophylaxis against varicella-zoster virus infection among recipients of hematopoietic stem cell transplant: unresolved issues. Infect Control Hosp Epidemiol. 2004; 25:603-608. [PubMed: 15301035]

87. American Academy of Pediatrics Committee on Infectious Diseases: The use of oral acyclovir in otherwise healthy children with varicella. Pediatrics. 1993; 91:674-676. [PubMed: 8382784]

88. Seward JF, Zhang JX, Maupin TJ, Mascola L, Jumaan AO. Contagiousness of varicella in vaccinated cases: a household contact study. Jama. 2004; 292:704-708. [PubMed: 15304467]

89. [June 2012] Zostavax in Renal Transplant Patients. ClinicalTrials.gov Identifier NCT01137669, from ClinicalTrials.gov

90. Safety and Immunogenicity of Zostavax Vaccine in Patients Undergoing Living Donor Kidney Transplantation. 2012 [June] ClinicalTrials.gov Identifier NCT00940940. from ClinicalTrials.gov.

91. Hata A, Asanuma H, Rinki M, Sharp M, Wong RM, Blume K, Arvin AM. Use of an inactivated varicella vaccine in recipients of hematopoietic-cell transplants. N Engl J Med. 2002; 347:26-34. [PubMed: 12097537] 
Table 1

Recommendations for VZV Treatment in Solid Organ Transplant Recipients

\begin{tabular}{|c|c|c|c|}
\hline Disease & Treatment & Evidence & Comments \\
\hline \multicolumn{4}{|l|}{ Outpatient Treatment } \\
\hline \multicolumn{4}{|l|}{ Herpes Zoster } \\
\hline $\begin{array}{r}\text { Localized } \\
\text { (Dermatomal) }\end{array}$ & $\begin{array}{l}\text { Acyclovir } \\
800 \mathrm{mg} \text { PO five times daily } \\
\text { (adults and children } \geq \mathbf{1 2} \\
\text { yrs) } \\
\text { OR } \\
\text { Valacyclovir } \\
1 \text { gram PO three times daily } \\
\text { (adults) } \\
20 \mathrm{mg} / \mathrm{kg} \text { PO three times } \\
\text { daily (children >2 and } \\
\mathbf{4 8} \text { ) years) } \\
\mathrm{OR}^{\dagger} \\
\text { Famciclovir } \\
500 \text { mg PO three times } \\
\text { daily (adults only) }\end{array}$ & Evidence II-1 & $\begin{array}{l}\text { - Oral therapy is not recommended for young children }<2 \\
\text { years of age, or patients with evidence of dissemination, } \\
\text { tissue invasion, HZ ophthalmicus or oticus, or those with } \\
\text { severe symptoms. These patients should be treated with IV } \\
\text { therapy (see below) } \\
\text { - Antivirals are typically given for at least } 7 \text { days or until lesions } \\
\text { have crusted over, which may be delayed in } \\
\text { immunocompromised hosts } \\
\text { - Valacyclovir and Famciclovir are not FDA approved for } \\
\text { treatment of herpes zoster, but are commonly used in clinical } \\
\text { practice } \\
\text { - Valacyclovir is only recommended for children } 22 \text { to } 18 \text { years } \\
\text { of age } \\
\text { - IV acyclovir is recommended in children }<2 \text { yrs of age [10 } \\
\text { mg/kg IV every } 8 \text { hours] or those who cannot tolerate oral } \\
\text { therapy } \\
\text { - Careful monitoring of renal function is needed while on high- } \\
\text { dose acyclovir therapy, and dosing should be adjusted for renal } \\
\text { insufficiency }\end{array}$ \\
\hline \multicolumn{4}{|l|}{ Inpatient Treatment } \\
\hline \multicolumn{4}{|l|}{ Acute Varicella } \\
\hline & $\begin{array}{l}\text { Acyclovir } \\
30 \mathrm{mg} / \mathrm{kg} \mathrm{IV} \text { in } 3 \text { divided } \\
\text { doses (adults and children } \\
<\mathbf{1} \text { year) } \\
\mathrm{OR} \\
1500 \mathrm{mg} / \mathrm{m}^{2} \mathrm{IV} \text { per day in } 3 \\
\text { divided doses (children }>1 \\
\text { year of age) }\end{array}$ & Evidence I & $\begin{array}{l}\text { - IV therapy can be changed to oral therapy once the patient has } \\
\text { significantly improved } \\
\text { • Careful monitoring of renal function is needed while on IV } \\
\text { therapy, and dosing should be adjusted for renal insufficiency }\end{array}$ \\
\hline \multicolumn{4}{|l|}{ Herpes Zoster } \\
\hline $\begin{array}{l}\quad \text { Disseminated or } \\
\text { Invasive Disease or } \\
\text { Herpes zoster } \\
\text { ophthalmicus or } \\
\text { Ramsay-Hunt syndrome/ } \\
\text { Herpes zoster oticus }\end{array}$ & $\begin{array}{l}\text { Acyclovir } \\
30 \mathrm{mg} / \mathrm{kg} \text { IV in } 3 \text { divided } \\
\text { doses (adults and } \\
\text { children) }\end{array}$ & & $\begin{array}{l}\text { - In disseminated disease IV therapy should be given for at for } \\
\text { at least } 7 \text { days, but may need to be given for longer in patients } \\
\text { with extensive involvement or CNS disease } \\
\text { - Ophthalmology consultation is recommended for patients with } \\
\text { ophthalmic involvement } \\
\text { - Consideration for switch to oral therapy dependent on patient's } \\
\text { clinical status } \\
\text { - Careful monitoring of renal function is needed while on IV } \\
\text { therapy, and dosing should be adjusted for renal insufficiency }\end{array}$ \\
\hline
\end{tabular}

* Data supporting IV therapy for herpes zoster ophthalmicus and oticus are Evidence level III

${ }^{\dagger}$ FDA approved dosing for children only in varicella not herpes zoster

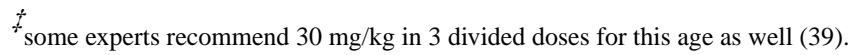

Am J Transplant. Author manuscript; available in PMC 2017 March 01. 
Table 2

Recommendations for VZV Prevention in Solid Organ Transplant Recipients

\begin{tabular}{|c|c|c|c|c|}
\hline Strategy & Pre-Transplant & Post-Transplant & Dosing & Comments \\
\hline \multicolumn{5}{|l|}{ Varicella/HZ Prevention } \\
\hline \multicolumn{4}{|l|}{ Antiviral Prophylaxis } & \multirow[b]{2}{*}{$\begin{array}{l}\text { - Evidence in other populations for } \\
\text { effectiveness against VZV, minimal } \\
\text { data in SOT recipients. } \\
\text { - IV acyclovir is recommended in } \\
\text { children <2 yrs of age [ } 5 \mathrm{mg} / \mathrm{kg} \text { IV } \\
\text { every } 8 \text { hours] or those who cannot } \\
\text { tolerate oral therapy } \\
\text { - Alternate less frequent dosing (BID) } \\
\text { for acyclovir has been described but } \\
\text { has not been evaluated in SOT } \\
\text { populations } \\
\text { - Patients receiving CMV prophylaxis } \\
\text { generally should be protected from } \\
\text { VZV reactivation } \\
\text { - Valacyclovir is only recommended } \\
\text { for children } 2 \text { to }<18 \text { years of age and } \\
\text { has not been studied as a prophylactic } \\
\text { agent in children post-SOT } \\
\text { - Lifelong risk of HZ limits use of } \\
\text { these agents for long-term prevention. }\end{array}$} \\
\hline Acyclovir (and pro-drugs) & N/A & $\begin{array}{l}\text { Short- term } \\
\text { prophylaxis is } \\
\text { recommended for } \\
\text { patients who are } \\
\text { HSV positive in } \\
\text { patients not receiving } \\
\text { CMV prophylaxis } \\
\text { (Evidence I). } \\
\text { Prophylaxis in VZV } \\
\text { seropositive } \\
\text { CMV/HSV } \\
\text { seronegative } \\
\text { recipients has not } \\
\text { been studied but can } \\
\text { be considered } \\
\text { (Evidence III) }\end{array}$ & $\begin{array}{l}\text { Acyclovir } \\
600-1000 \\
\text { mg/day PO in } \\
3-5 \text { divided } \\
\text { doses (adults } \\
\text { and children } \geq \\
\mathbf{2} \text { yrs) } \\
\text { Max dose in } \\
\text { children is 80 } \\
\text { mg/kg/day not } \\
\text { to exceed 3200 } \\
\text { mg/day } \\
\text { See reference } \\
39 \text { for dosing } \\
\text { in children }<2 \\
\text { yrs } \\
\text { OR } \\
\text { Valacyclovir } \\
500 \text { mg PO } \\
\text { twice daily } \\
\text { (adults only) }\end{array}$ & \\
\hline \multicolumn{4}{|l|}{ Vaccination } & \multirow{3}{*}{$\begin{array}{l}\text { - Vaccination has been shown to be } \\
\text { safe in ESRD and ESLD patients } \\
\text { - Seroconversion rate reduced in } \\
\text { immunosuppressed individuals } \\
\text { - Caution should be used in post- } \\
\text { transplant patients since live virus } \\
\text { vaccine } \\
\cdot 2^{\text {nd }} \text { dose can be given } 4 \text { to } 8 \text { weeks } \\
\text { after first in adults, but must be } \\
\text { delayed till } \geq 3 \text { months after } 1^{\text {st }} \text { dose } \\
\text { in children }<13 \text { years of age (see } \\
\text { package insert for guidelines) } \\
\text { - Follow label indications, as no } \\
\text { evidence that vaccine is safe in severe } \\
\text { organ dysfunction or post-transplant } \\
\text { - If patient meets label indications can } \\
\text { be considered, but should be given at } \\
\text { least } 3-4 \text { weeks prior to transplant. }\end{array}$} \\
\hline Varicella Vaccine (Varivax $\left.{ }^{\circledR}\right)$ & $\begin{array}{l}\text { YES, if seronegative } \\
\text { (Evidence II-1) }\end{array}$ & $\begin{array}{c}\text { Consider if } \\
\text { susceptible in select } \\
\text { populations } \\
\text { (Evidence III) }\end{array}$ & $\begin{array}{l}\text { Varivax® } 0.5 \\
\mathrm{~mL} \\
\text { administered } \\
\mathrm{SQ}\end{array}$ & \\
\hline Zoster Vaccine (Zostavax®) & $\begin{array}{l}\text { No for most } \\
\text { transplant recipients } \\
\text { (Evidence III), } \\
\text { unless patient meets } \\
\text { label indications } \\
\text { (Evidence I) }\end{array}$ & No (Evidence III) & N/A & \\
\hline \multicolumn{5}{|c|}{ Post-Exposure Prophylaxis (serongative patients only) } \\
\hline \multicolumn{4}{|l|}{ Immunoprophylaxis } & \multirow{3}{*}{$\begin{array}{l}\text { - VariZIG is only available through } \\
\text { IND protocol }{ }^{\dagger} \\
\text { - Must be given as soon as possible- } \\
\text { no efficacy if given more than } 10 \text { days } \\
\text { post-exposure } \\
\text { - Not } 100 \% \text { effective in clinical } \\
\text { studies of preventing VZV, so close } \\
\text { observation is suggested } \\
\text { - If varicella develops, patient should } \\
\text { be treated with antiviral therapy } \\
\text { - Amount of anti-VZV antibodies in } \\
\text { IVIG is variable, and should only be } \\
\text { considered if VZV specific } \\
\text { immunoglobulin therapy is not } \\
\text { available }\end{array}$} \\
\hline $\begin{array}{l}\text { VZV immunoglobulin } \\
\left.\text { (VZIG, VariZIG }{ }^{\mathrm{TM}}\right)\end{array}$ & $\begin{array}{l}\text { YES, if seronegative } \\
\text { (Evidence II-1) }\end{array}$ & $\begin{array}{l}\text { YES, if seronegative } \\
\text { (Evidence II-1) }\end{array}$ & $\begin{array}{l}\text { VariZIG } \\
125 \text { units } / 10 \mathrm{~kg} \\
\text { body weight in } \\
\text { single IM dose } \\
\text { (Max dose is } \\
625 \text { units, min } \\
125 \text { units) }\end{array}$ & \\
\hline $\begin{array}{l}\text { IV immunoglobulin (non- } \\
\text { specific IVIG) }\end{array}$ & $\begin{array}{c}\text { Consider, if } \\
\text { seronegative and } \\
\text { VZIG or VariZIG } \\
\text { not available } \\
\text { (Evidence III) }\end{array}$ & $\begin{array}{c}\text { Consider, if } \\
\text { seronegative and } \\
\text { VZIG or VariZIG not } \\
\text { available (Evidence } \\
\text { III) }\end{array}$ & $\begin{array}{l}\text { IVIG } \\
400 \mathrm{mg} / \mathrm{kg} \text { IV } \\
\text { single dose }\end{array}$ & \\
\hline \multicolumn{4}{|l|}{ Antiviral Prophylaxis } & $\begin{array}{l}\text { - Given 7-10 days after exposure for } 7 \\
\text { days }\end{array}$ \\
\hline
\end{tabular}




\begin{tabular}{|c|c|c|c|c|}
\hline Strategy & Pre-Transplant & Post-Transplant & Dosing & Comments \\
\hline$\underset{\text { drugs) }}{\text { Acyclovir }}{ }^{\dagger}$ (and pro- & $\begin{array}{c}\text { Consider, if } \\
\text { seronegative and } \\
\text { VZIG or VariZIG } \\
\text { not available or in } \\
\text { addition to } \\
\text { immunoprophylaxis } \\
\text { (Evidence III) }\end{array}$ & $\begin{array}{c}\text { Consider, if } \\
\text { seronegative and } \\
\text { VZIG or VariZIG not } \\
\text { available or in } \\
\text { addition to } \\
\text { immunoprophylaxis } \\
\text { (Evidence III) }\end{array}$ & $\begin{array}{l}\text { Acyclovir } \\
800 \mathrm{mg} \text { PO } \\
\text { four times } \\
\text { daily (adults) } \\
20 \mathrm{mg} / \mathrm{kg} \text { PO } \\
\text { four times } \\
\text { daily } \\
\text { (maximum } \\
\mathbf{8 0 0} \mathbf{m g} \text { four } \\
\text { times a day, } \geq \\
\mathbf{2} \text { yrs of age) } \\
30 \mathrm{mg} / \mathrm{kg} \text { IV } \\
\text { per day in } 3 \\
\text { divided doses } \\
\text { (adults and } \\
\text { children) } \\
\text { OR } \\
\text { Valacyclovir } \\
1 \text { gram PO } \\
\text { three times } \\
\text { daily (adults) }\end{array}$ & $\begin{array}{l}\text { - Alternatively, some experts } \\
\text { recommend dosing being given days } \\
3-22 \text { after exposure (or till day } 28 \text { if } \\
\text { given immunoprophylaxis) } \\
\text { - Caution with patients with } \\
\text { underlying renal dysfunction as dosing } \\
\text { may need to be reduced } \\
\text { - IV acyclovir is recommended in } \\
\text { children <2 yrs of age or those who } \\
\text { cannot tolerate oral therapy } \\
\text { - Valacyclovir is only recommended } \\
\text { for children } 2 \text { to < } 18 \text { years of age and } \\
\text { has not been studied as a prophylactic } \\
\text { agent in children post-SOT }\end{array}$ \\
\hline
\end{tabular}

VZV= Varicella zoster virus, HSV = Herpes simplex virus, HZ = Herpes zoster, SOT = Solid organ transplant, ESRD= End-stage renal disease, ESLD $=$ End-stage liver disease

${ }^{\dagger}$ Contact information for VariZIG is available online at: (http://www.cdc.gov/mmwr/preview/mmwrhtml/mm55e224a1.htm)

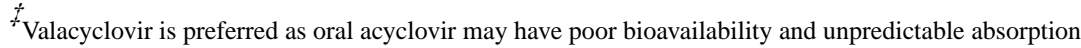

